\title{
GMR
}

\section{Effect of organic matter enrichment on the fungal community in limestone cave sediments}

\author{
E.L.S. Marques ${ }^{1}$, J.C.T. Dias ${ }^{2}$, G.S. Silva ${ }^{1}$, C.P. Pirovani ${ }^{3}$ and R.P. Rezende ${ }^{1,2}$ \\ ${ }^{1}$ Laboratório de Biotecnologia Microbiana, Departamento de Ciências Biológicas, \\ Universidade Estadual de Santa Cruz, Ilhéus, BA, Brasil \\ ${ }^{2}$ Laboratório de Monitoramento Ambiental, Departamento de Ciências Biológicas, \\ Universidade Estadual de Santa Cruz, Ilhéus, BA, Brasil \\ ${ }^{3}$ Departamento de Ciências Biológicas, Universidade Estadual de Santa Cruz, \\ Ilhéus, BA, Brasil \\ Corresponding author: R.P. Rezende \\ E-mail: rezende.rachel@gmail.com
}

Genet. Mol. Res. 15 (3): gmr.15038611

Received March 8, 2016

Accepted April 25, 2016

Published September 2, 2016

DOI http://dx.doi.org/10.4238/gmr.15038611

Copyright (C) 2016 The Authors. This is an open-access article distributed under the terms of the Creative Commons Attribution ShareAlike (CC BY-SA) 4.0 License.

ABSTRACT. Caves are considered major touristic attractions. The
management plans of many such caves include limiting the number of
visitors; however, the human impact on microbial communities within
caves is rarely considered. Therefore, the aim of this study was to
evaluate the impact of human-transferred organic matter on the fungal
microcosms growing on cave sediments. Samples were collected from
a Brazilian limestone cave and cultured with 0.25 or $0.5 \% 1: 1$ (w/w)
beef and yeast extract (simulating organic matter) under laboratory
conditions. The contaminated fungal community was then evaluated
at days $0,30,180$, and 365 after inoculation by polymerase chain
reaction denaturing gradient gel electrophoresis. We observed changes

Genetics and Molecular Research 15 (3): gmr.15038611 
in the fungal communities with time, as well as the concentration of added organic matter, compared to the control fungal communities. Additionally, the contaminated microcosms showed a greater number of operational taxonomic units compared to the controls. These findings suggest that tourist activity could cause fungal outbreaks of possible human pathogens, demonstrating the importance of fungal monitoring in these caves.

Key words: Beef extract; Yeast extract; Microcosms; PCR-DGGE; Cave sediment

\section{INTRODUCTION}

Caves are major tourist attractions worldwide that allow people to explore the subterranean regions of the earth. However, tourism has been shown to negatively impact the environmental factors within the cave, including the temperature, $\mathrm{CO}_{2}$ concentration, and organic matter and microorganism content (Šebela et al., 2013; Mulec, 2014). Specifically, the development of microbial bloom in caves is extremely difficult to control and recover from (Mulec and Kosi, 2009; Jurado et al., 2010b); moreover, microbial bloom affects the attractiveness of the cave, influencing tourism, and could also be responsible for cave closure, due to the risk to human health and cave conservation (Jurado et al., 2010b; Saiz-Jimenez et al., 2011).

Fungi are commonly associated with caves that are tourist attractions or those with high organic matter (Nieves-Rivera et al., 2009; Nováková, 2009). Uncontrolled and widespread fungal growth is responsible for the temporary closure of several tourist caves, necessitating biocide treatment to eliminate the targeted fungi as well as several native microorganisms of these caves (Bastian et al., 2009, 2010; Jurado et al., 2010b; Martin-Sanchez et al., 2012b). These measures are taken to avoid risk to human health; however, not enough information is available regarding the effect of tourism on cave microorganisms, as a majority of the studies compare the microbial bloom in the tourist and non-tourist parts of the cave or among caves in the same area (Chelius and Moore, 2004; Adetutu et al., 2011). Therefore, the data could be misinterpreted because of the natural variations in the cave or among different caves. Therefore, the aim of this study was to evaluate the effect of organic matter enrichment on the fungal community colonized in the microcosm sediment in the organic matter-enriched Manoel Ioiô cave.

\section{MATERIAL AND METHODS}

\section{Sampling and microcosm preparation}

Sediment samples were collected from the Manoel Ioiô cave $\left(12^{\circ} 20^{\prime} 9.96 " \mathrm{~S}\right.$, $41^{\circ} 33^{\prime} 50.04^{\prime \prime} \mathrm{W}$ ) located in Iraquara, Bahia, Brazil (SISBIO authorization No. 38453). Samples were collected within the cave, $500 \mathrm{~m}$ from the entrance. Five subsamples collected $1 \mathrm{~m}$ apart from one another were mixed to form a composite sample. Organic matter present in the soil was $<5 \mathrm{~g}$ of the organic matter present per kilogram of sediment.

Microcosms were set up in triplicate in $250 \mathrm{~mL}$ Erlenmeyer flasks. Each microcosm contained $75 \mathrm{~g}$ sediment and 0.25 or $0.5 \% 1: 1$ yeast and beef extract mixture diluted in 10 $\mathrm{mL}$ distilled water (mimicking the organic matter contamination caused by tourists). Control microcosms contained sediments and distilled water. All microcosms were incubated in the dark at approximately $25^{\circ} \mathrm{C}$.

Genetics and Molecular Research 15 (3): gmr.15038611 


\section{Sampling from microcosms, DNA extraction, and PCR}

Sediment samples were homogenized briefly and aseptically collected from microcosms on days $0,30,180$, and 365 after culture induction. One-gram samples were collected in triplicate and mixed; a quarter of the sample $(250 \mathrm{mg})$ was used for DNA extraction using the MoBio PowerSoil ${ }^{\mathrm{TM}}$ DNA kit (MoBio Laboratories Inc., Carlsbad, CA, USA) according to the manufacturer protocols.

PCR was performed in a thermocycler (Eppendorf, Hamburg, Germany) using fungusspecific primers EF4 (5'-GGA AGG G[G/A]T GTA TTT ATT A-3') and fung5r (5'-T AAA AGT CCT GGT TCC C-3') (van Elsas et al., 2000). A GC-clamp (5'-CGC CCG CCG CGC GCG GCG GGC GGG GCG GGG G-3') (Muyzer et al., 1993) was attached to the fung5r primer. PCR was performed in a $25-\mu \mathrm{L}$ reaction mixture containing $0.2 \mu \mathrm{M}$ each primer, 0.2 $\mathrm{mM}$ dNTP (each), $1.25 \mathrm{U}$ Taq DNA polymerase (Invitrogen, São Paulo, Brazil), $3 \mathrm{mM} \mathrm{MgCl}$, 1X PCR buffer, and approximately 60 ng DNA.

\section{Denaturing gel electrophoresis (DGGE)}

The samples were subjected to DGGE in a DCode universal mutation detection system (Bio-rad Laboratories, Hercules, CA, USA). The amplicons were electrophoresed on an $8 \%$ polyacrylamide gel $(\mathrm{w} / \mathrm{v})(37.5: 1$ acrylamide:bisacrylamide) prepared in a denaturing gradient of 30-60\% [4 M urea and 40\% (v/v) formamide is indicative of a $100 \%$ denaturing gradient], in TAE $1 \mathrm{X}$ buffer for $16 \mathrm{~h}$ at $70 \mathrm{~V}$ and $60^{\circ} \mathrm{C}$. The gel was stained with silver nitrate (modified from Benbouza et al., 2006) at environmental temperature and $0.65 \%$ sodium carbonate was added to the developing solution after 3 min. The presence and absence of bands were presented as a binary matrix to allow for principal component analysis and dendrogram analysis using the Jaccard coefficient. Both analyses were performed on the PAST 3.0 software platform (folk.uio.no/ohammer/past/). Moreover, a Venn diagram was prepared manually.

\section{RESULTS}

Microcosms contaminated with yeast and beef extract showed a higher number of operational taxonomic units (OTUs) compared to the controls (Figure 1). We observed a decrease in the number of visible OTUs in DGGE after 12 months; however, their profile was similar to those of contaminated samples (Figures 2 and 3). The yeast and beef extract mixture showed different effects at different concentrations. The $0.5 \%$ contaminating mixture presented more bands during the first month; however, this profile changed at 6 months (Figure 1). We also observed changes between the microcosm profiles of the contaminated samples incubated for 1 and 6 months; however, the samples with different contaminating concentrations showed similar profiles at the same time. On the other hand, the samples incubated $0.5 \%$ of yeast and beef extract showed a similar profile for 6 and 12 months (Figure 2). The controls presented similar profiles (Figures 1 and 2) and the lowest number of bands.

Genetics and Molecular Research 15 (3): gmr.15038611 


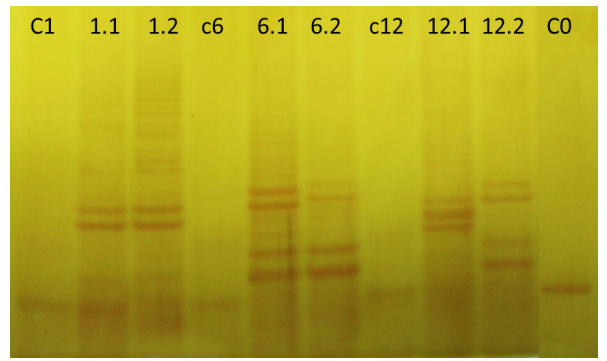

Figure 1. Denaturing gel gradient electrophoresis of fungi from cave sediments contaminated with organic matter. Representative samples of three independent experiments are shown. Controls are denoted as C. The numbers before dots or after " $\mathrm{C}$ " indicate the month of sampling and the numbers after dots indicate the concentration $(1=$ $0.25 \%$ and $2=0.5 \% 1: 1$ yeast and beef extract mixture).

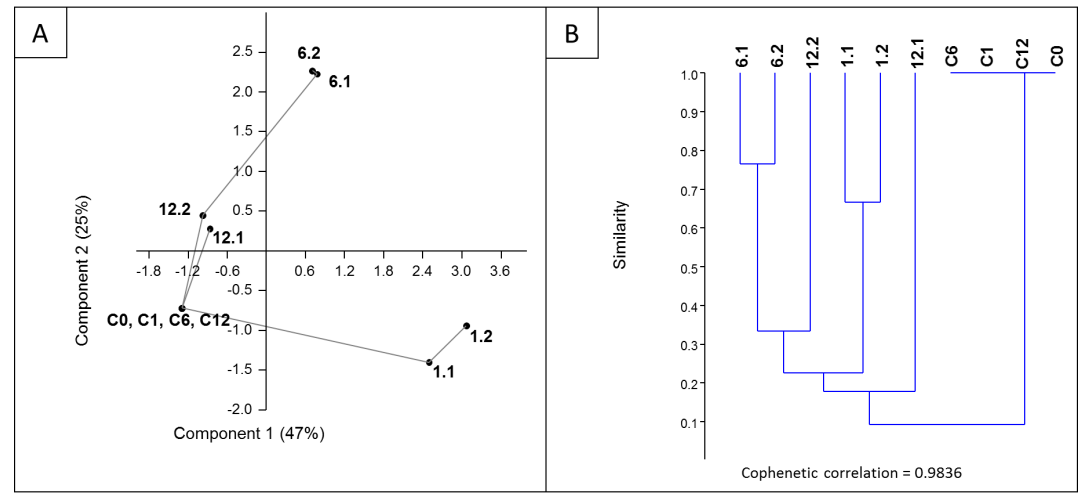

Figure 2. Principal component analysis and dendrogram analysis using the Jaccard coefficient of similarity in fungal profiles observed by DGGE. The number before dots or after "C" indicates the month of sampling and the number after dots indicates the concentration $(1=0.25 \%$ and $2=0.5 \% 1: 1$ yeast and beef extract mixture $)$.

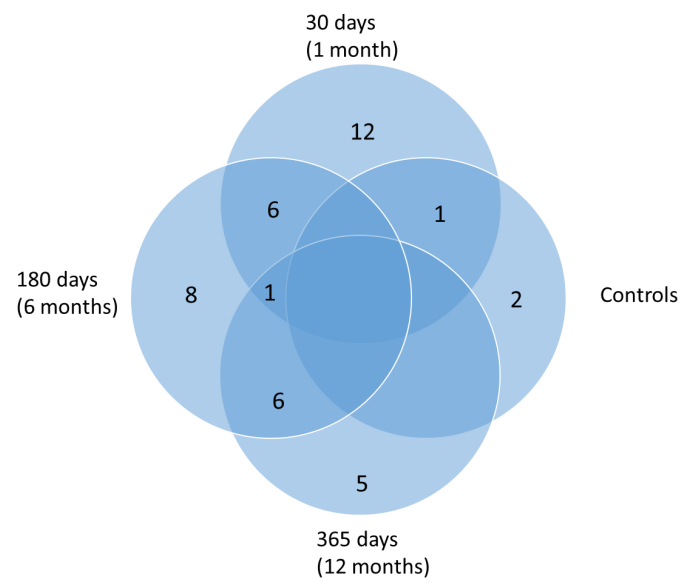

Figure 3. Venn diagram of operational taxonomic units shared among the beef and yeast extract mixturecontaminated fungal microcosms incubated for various time periods, irrespective of the concentrations and controls.

Genetics and Molecular Research 15 (3): gmr.15038611 
The Venn diagram bands were similar across the various time intervals (Figure 3). A large number of bands were shared between the contaminated fungal samples incubated for 1 and 6 months and 6 and 12 months. The controls shared only one band with a 1-month-long contaminated microcosm, and presented two exclusive bands (Figure 3).

\section{DISCUSSION}

Human visitation in caves has affected their intrinsic microbial communities (Chelius and Moore, 2004; Ikner et al., 2007; Adetutu et al., 2011; Saiz-Jimenez, 2012). Although the changes in the OTUs were detected along the course of the experiment (Figures 1-3), only one of many contaminant factors was analyzed. The presence of artificial light has been shown to increase the development of photosynthetic organisms (Chelius and Moore, 2004; Mulec et al., 2012), while external organisms transported by visitors could generate different changes in the microbial community (Mulec and Kosi, 2009). Controlling these factors allows for evaluation of the effect of organic matter on the fungal communities in cave sediments. Beef and yeast extracts were chosen for their chemical similarity to components carried by visitors into caves, dead skin cells and other microorganisms; however, other nutrients, such as the ones present in lint, hair, and oils, could not be included (Adetutu et al., 2011) because of the difficulty in simulating and controlling the amount of contamination in the lab.

In situ studies could provide better and more reliable results regarding the lack of conservation of caves that are open to tourists. However, this is not a feasible proposition. Further difficulties include the prediction of the number of tourists who would visit a recently opened cave. Caves in areas such as Chapada Diamantina that are newly opened to tourists could have a low visitation percentage during the starting stages. This would necessitate an increase in the experimental time up to an unpredicted period, until the number of visitors reaches that of famous or partially famous caves. These measures could increase the feasibility of microcosm studies. Caves that are already open for tourism do not provide us with a view of the theoretical pristine fungal community in caves, as changes in both concentrations can be visualized at 30 days (Figures 1-3).

Studies that are dependent on, and independent of, fungal cultures, show that these variations could be expected in the controls (Adetutu et al., 2011; Taylor et al., 2013). Cave fungi are commonly described as opportunistic organisms that increase their population based solely on the inflow of organic matter (Nieves-Rivera et al., 2009; Jurado et al., 2010b; Saiz-Jimenez, 2012). This information supports the findings of our research. The increased number of bands is representative of the increase in the number of fungal OTUs. DGGE only detects bands that are represented significantly in a community $(>1 \%)$ following primer amplification (Muyzer et al., 1993). Fungi remain almost undetected in an unfavorable cave environment; therefore, the three bands detected in controls could be representative of an unknown metabolically active fungus or an unknown source that transports these fungi within the cave. In caves that are open for tourists, the bloom of these types of fungi could result in a temporary closure of the cave (Jurado et al., 2010b), requiring a biocide treatment prior to reopening (Jurado et al., 2010b; Martin-Sanchez et al., 2012b).

Fungal proliferation is known to differ based on the concentration of organic matter (Figures 1 and 2). Fungal microcosms cultured with the highest amount of organic matter $(0.5 \%)$ showed a greater number more bands during the first few months of growth; however, the number of representative OTUs (seen during the first few months) decreased during

Genetics and Molecular Research 15 (3): gmr.15038611 
months 6 and 12, which could be attributed to the possible exhaustion of the available organic matter. However, this was not seen in fungi cultured with $0.25 \%$ organic matter: several weak bands were detected at 6 and 12 months after culture (Figure 1). Organic matter contamination and fungal widespread are relatively common in caves open for tourist visits (Jurado et al., 2010b; Martin-Sanchez et al., 2012a,b), these findings indicate an alarming scenario as a small amount of organic matter could generate a fungal bloom despite the lack of other factors associated with these caves (Mulec and Kosi, 2009; Jurado et al., 2010b; Porca et al., 2011; Martin-Sanchez et al., 2012b; Šebela et al., 2013; Mulec, 2014). Several species of fungi are human pathogens and could be transported by visitors and proliferate in the closed environment of these caves (Jurado et al., 2010a; Taylor et al., 2013), which could be a major health risk to anyone who enters the cave.

These findings demonstrate the importance of fungal study in caves open for tourists. The fungal community in caves must be monitored periodically to avoid abnormal proliferation, which could put visitors at a health risk. Culture-dependent and culture-independent methods used to monitor fungi in caves should be evaluated and included in the management plans for caves.

\section{Conflicts of interest}

The authors declare no conflict of interest.

\section{ACKNOWLEDGMENTS}

Research supported by grants provided by Conselho Nacional de Desenvolvimento Científico e Tecnológico (\#482721/2012-0); E.L.S. Marques was supported by a doctoral fellowship from Fundação de Amparo à Pesquisa do Estado da Bahia (\#BOL0849/2012). The authors would like to thank the speleological group at the Museu de História Natural da Universidade Federal de Alagoas, especially Dr. Jorge Luiz Lopes da Silva, for their assistance during sampling.

\section{REFERENCES}

Adetutu EM, Thorpe K, Bourne S, Cao X, et al. (2011). Phylogenetic diversity of fungal communities in areas accessible and not accessible to tourists in Naracoorte Caves. Mycologia 103: 959-968. http://dx.doi.org/10.3852/10-256

Bastian F, Alabouvette C and Saiz-Jimenez C (2009). Bacteria and free-living amoeba in the Lascaux Cave. Res. Microbiol. 160: 38-40. http://dx.doi.org/10.1016/j.resmic.2008.10.001

Bastian F, Jurado V, Nováková A, Alabouvette C, et al. (2010). The microbiology of Lascaux Cave. Microbiology 156: 644-652. http://dx.doi.org/10.1099/mic.0.036160-0

Benbouza H, Jacquemin J-M, Baudoin J-P and Mergeai G (2006). Optimization of a reliable, fast, cheap and sensitive silver staining method to detect SSR markers in polyacrylamide gels. Biotechnol. Agron. Société Environ. 10: 77-81.

Chelius MK and Moore JC (2004). Molecular phylogenetic analysis of Archaea and Bacteria in Wind Cave, South Dakota. Geomicrobiol. J. 21: 123. http://dx.doi.org/10.1080/01490450490266389

Ikner LA, Toomey RS, Nolan G, Neilson JW, et al. (2007). Culturable microbial diversity and the impact of tourism in Kartchner Caverns, Arizona. Microb. Ecol. 53: 30-42.http://dx.doi.org/10.1007/s00248-006-9135-8

Jurado V, Laiz L, Rodriguez-nava V, Boiron P, et al. (2010a). Pathogenic and opportunistic microorganisms in caves. Int. J. Speleol. 39: 15-24. http://dx.doi.org/10.5038/1827-806X.39.1.2

Jurado V, Porca E, Cuezva S, Fernandez-Cortes A, et al. (2010b). Fungal outbreak in a show cave. Sci. Total Environ. 408: 3632-3638. http://dx.doi.org/10.1016/j.scitotenv.2010.04.057

Martin-Sanchez PM, Bastian F, Alabouvette C and Saiz-Jimenez C (2012a). Real-time PCR detection of Ochroconis lascauxensis involved in the formation of black stains in the Lascaux Cave, France. Sci. Total Environ. 443: 478-484. http://dx.doi.org/10.1016/j.scitotenv.2012.11.026

Genetics and Molecular Research 15 (3): gmr.15038611 
Fungal community and organic matter in limestone caves

Martin-Sanchez PM, Nováková A, Bastian F, Alabouvette C, et al. (2012b). Use of biocides for the control of fungal outbreaks in subterranean environments: the case of the Lascaux Cave in France. Environ. Sci. Technol. 46: 37623770. http://dx.doi.org/10.1021/es2040625

Mulec J (2014). Human impact on underground cultural and natural heritage sites, biological parameters of monitoring and remediation actions for insensitive surfaces: Case of Slovenian show caves. J. Nat. Conserv. 22: 132-141. http:// dx.doi.org/10.1016/j.jnc.2013.10.001

Mulec J and Kosi G (2009). Lampenflora algae and methods of growth control. J. Cave Karst Stud. 71: 109-115.

Mulec J, Krišstůfek V and Chroňáková A (2012). Monitoring of microbial indicator groups in caves through the use of RIDA $^{\circledR}$ COUNT kits. Acta Carsologica 42: 287-296.

Muyzer G, de Waal EC and Uitierlinden AG (1993). Profiling of complex microbial populations by denaturing gradient gel electrophoresis analysis of polymerase chain reaction-amplified genes. Appl. Environ. Microbiol. 59: 695-700.

Nieves-Rivera ÁM, Santos-Flores CJ, Dugan FM and Miller TE (2009). Guanophilic fungi in three caves of southwestern Puerto Rico. Int. J. Speleol. 38: 61-70. http://dx.doi.org/10.5038/1827-806X.38.1.7

Nováková A (2009). Microscopic fungi isolated from the Domica Cave system (Slovak Karst National Park, Slovakia). A review. Int. J. Speleol. 38: 71-82. http://dx.doi.org/10.5038/1827-806X.38.1.8

Porca E, Jurado V, Martin-Sanchez PM, Hermosin B, et al. (2011). Aerobiology: An ecological indicator for early detection and control of fungal outbreaks in caves. Ecol. Indic. 11: 1594-1598. http://dx.doi.org/10.1016/j.ecolind.2011.04.003

Saiz-Jimenez C (2012). Microbiological and environmental issues in show caves. World J. Microbiol. Biotechnol. 28: 2453-2464. http://dx.doi.org/10.1007/s11274-012-1070-x

Saiz-Jimenez C, Cuezva S, Jurado V, Fernandez-Cortes A, et al. (2011). Paleolithic art in peril : Policy and science collide at Altamira cave. Science 334: 42-43. http://dx.doi.org/10.1126/science.1206788

Šebela S, Prelovšek M and Turk J (2013). Impact of peak period visits on the Postojna Cave (Slovenia) microclimate. Theor. Appl. Climatol. 111: 51-64. http://dx.doi.org/10.1007/s00704-012-0644-8

Taylor ELS, Resende Stoianoff MA and Lopes Ferreira R (2013). Mycological study for a management plan of a neotropical show cave (Brazil). Int. J. Speleol. 42: 267-277. http://dx.doi.org/10.5038/1827-806X.42.3.10

van Elsas JD, Duarte GF, Keijzer-Wolters A and Smit E (2000). Analysis of the dynamics of fungal communities in soil via fungal-specific PCR of soil DNA followed by denaturing gradient gel electrophoresis. J. Microbiol. Methods 43: 133-151.http://dx.doi.org/10.1016/S0167-7012(00)00212-8

Genetics and Molecular Research 15 (3): gmr.15038611 